$\xi=1$ 国

\title{
Classification of Dengue using Machine Learning Techniques
}

\author{
T.Sajana ${ }^{1}$, M.Navya ${ }^{2}$, YVSSV $^{2}$.Gayathri ${ }^{2}$, N.Reshma ${ }^{2}$ \\ ${ }^{1}$ Assistant Professor, Department of CSE, K L E F, Vaddeswaram, Guntur, Andhra Pradesh, India 522502 \\ ${ }^{2}$ B.Tech Students, Department of CSE, K L E F, Vaddeswaram, Guntur, Andhra Pradesh, India 522502 \\ *Corresponding author E-mail: sajana.cse@kluniversity.in
}

\begin{abstract}
Dengue infection belongs to the family of virus, Flaviviridae, consisting of four serotypes which spread through the chomp of contaminated Aedes mosquitoes. Around 2.5 billion individuals live in dengue-hazard locales with around 100 million new cases every year around the world. The worldwide predominance of dengue has grown dramatically in later decades. The illness is now endemic in more than 100 nations in Africa, the Americas, the eastern Mediterranean, South East Asia and the western pacific south Asia and the western pacific are the most genuinely influenced. In 1970's only nine nations had encountered DHF plagues, a number which had expanded more than four- crease by 1995[30].Numerous clinical signs are utilized for diagnosing of fever. In any case, it has been an awesome test for the doctors to distinguish the level of hazard in dengue patients utilizing clinical indications. But the disadvantages of clinical procedures make machine learning more powerful in diagnosing of fever in affected patients. Subsequently, this study plans to apply a non-invasive machine learning techniques to help the doctors for ordering the hazard in dengue patients. Conducted a comparison study among Simple Classification and Regression Tree(CART), Multi-layer perception (MLP) and C4.5 algorithms, based on which demonstrating that Simple CART algorithm shows 100\% accuracy for classification of affected or unaffected patient.
\end{abstract}

Keywords:Dengue, Aedes, Simple CART, Multi-layer Perception, C4.5 and Accuracy..

\section{Introduction}

Dengue fever is an irresistible illness likewise called as a break borne fever or dandy fever or dengue haemorrhagic fever caused by a group of virus which are transmitted by mosquitoes. The family of mosquitoes which transmits dengue virus will also leads into diseases like chikungunya, yellow fever and zika virus[29][31]. Zika and dengue infections are classified as biological safety level (BSL) 2 pathogens while chikungunya virus is classified as a BSL-3 agent. The symptoms of Zika are comparable to those of dengue and chikungunya, which are infections caused by other viruses spread by the same sort of mosquitoes [32].The virus is ordered into four serotypes alluded to as DV-1, DV-2, DV-3 and DV-4, where DV is a positive-stranded epitomized RNA infection. It is made out of three basic protein qualities, which encode the nucleocapsid or core (C) protein, a membrane-associated (M) protein, an enveloped (E) glycoprotein and seven nonstructural (NS) proteins [24]. According to WHO report, in 2015 , India recorded a severe outbreak since 2006 with more than 15000 cases. Americans reported more than 2.38 million cases in 2016 and 50172 cases of dengue fever in 2017 , a reduction as compared with previous years, it estimates that 50 to 100 million infections occur early which include 5lakh dengue fever cases and 22,000 deaths,moslty among children[36].Virus can influence anybody yet is more extreme in immunodeficiency individuals. This contamination is caused through the chomp of Aedes aegypti, a female mosquito. Alternate mosquitoes get contaminated due to the admission of the blood from a man who is tainted with dengue infection. It is most regularly found in the areas of and subtropical atmospheres around the world [34].As there is no eco- nomically accessible immunization, avoidance is sought by diminishing the living space and the number of mosquitoes and restricting presentation to bites. Treatment of intense dengue is steady, utilizing either oral or intravenous re-hydration for gentle or direct disease, and intravenous liquids and furthermore blood transfusion for additional extreme situations [27]. Individuals who are presented to tainted mosquitoes will get the fever through the chomp of that mosquito. Just the contaminated female mosquitoes transmit the infection into the group of people. People will get the infection because of the bite of this contaminated mosquito. In the event that the sound mosquitoes chomp the contaminated people then following a week or over, these mosquitoes transmits the infection to the next solid individuals. This infection is a nontransmissible one as it can't be specifically spread from one individual to the next individual i.e; it isn't a human-to-human transmissible infection. It is ordinarily a human-to-mosquito-to-human cycle of transmission of the infection in people. Going to the kind of mosquito which causes dengue fever is known to be a day gnawing mosquito which implies that this sort of mosquitoes are dynamic amid daytime instead of evenings. The mosquito of the Aedes aegypti sort otherwise called yellow fever mosquito has a capacity to spread ailments like dengue fever, Chikungunya, yellow fever infections and so on[34]. The aedes aegypti mosquito is the same mosquito that is responsible for the transmission of dengue fever among humans[31][32][34].These mosquitoes are generally dim and are little in size of roughly 4 to 7 millimetres with white markings on their legs and a checking of the type of a lyre on their thorax. The tainted mosquitoes will contain infection in their salivary organs. At the point when a female mosquito nibbles a human then it will infuse its spit into the injury. Rainstorm sea- 
son and stale waters gives a place to rearing of these mosquito sorts and these mosquitoes generally rests at the inside and at some other dull places.[7] The Aedes aegypti sort mosquitoes for the most part comes in three polytypic frames to be specific sylvan, local and periodomesti.[25]. Symptoms begin from 4 to 7 days after transmission of infection into the human body by the mosquito.chikunguniya and zika fever have similar symptoms of dengue fever [31][32].That is the malaria, yellow fever, dengue fever, west Nile virus and somewhat Encephalitis. Mosquitoes can cause more than itchy, annoying bumps [34].Dengue fever is regularly mixed up for malaria fever, the flu (influenza) or something else. Intestinal sickness can be avoided by a blood test, and the sign of dengue can be inferred by a blood test. Recuperation will take time, with tiredness sometimes enduring a few weeks. Inquire about uncovered that the Aedes aegypti mosquito that carries dengue does not travel distant from its breeding put, not at all like other species of mosquito, which clarifies why dengue episodes tend to occur in localized ranges of a few hundred meters span[34].Dengue fever and Chikungunya flare-ups advance quickly, requiring crisis activities to quickly control infected mosquitoes in arrange to hinder or reduce transmission and to diminish or kill the breeding sites of the vector mosquito, aegypti[31].This infection begins circling in the blood of a contaminated individual for 2-7 days, at around the similar time individuals develop fever. In vast majority of the people the time-course of the disease is around 10-14 days i.e, two weeks, which is trailed by seven days of intense side effects and a couple of days of recuperation and at times the indications frequently reach out past two weeks for a regular dengue contamination. Manifestations and indications of the contamination for the most part incorporates a high fever of around $104 \mathrm{~F}-105 \mathrm{~F}$, skin rash, torment incorporates migraine and serious muscle and joint agonies and so forth. Kids regularly encounter the manifestations which are indistinguishable to those of the basic cold and gastroenteritis like retching and diarrhoea. Although the initial symptoms are generally mild but they even possess a greater risk of severe and intense complications and sometimes include a high fever. For chikunguniya, zika fever, dengue fever have no specific treatment [31][32][34]. Several vaccines are beneath advance. Such as live weakened virus vaccines, live chimeric infection antibody, inactivated virus vaccine and live recombinant, DNA and subunit vaccines. on viral immunizations are moreover proposed and developed. Papaya (Carica papaya) and Neem are actually utilized to cure dengue fever [28].

\section{Literature Review}

Various researchers conducted clinical studies for prediction of dengue fever as follows:

Essential methodologies for the investigation of the sickness are clinical examination or clinical manifestations. Clinical appearances were done on record based investigation for deciding the profile and result of the considerable number of patients with a finding of dengue. Out of 466 cases with positive ELISA test, 391 had dengue, 41 had DHF and 34 had DSS [19]. Clinical examinations were done on 140 patients with DF. Thrombocytopenia was the commonest haematological variation from the norm. Mortality was found in 5 patients [15]. 1664 individuals in Hawaii were gone under immune response and antigen tests, $\operatorname{IgG}$ and $\operatorname{IgM}$ for dengue recognition. Out of which 122 people are dengue positive [20]. Elisa test was performed on 2259 residents of german after their arrival from dengue endemic nations. Results demonstrate that individuals with intense disease are $4.7 \%$ [23]. Diagnosing of the dengue fever at atomic level is done by utilizing a blend of RT_LAMP and paper based gadgets made with the assistance of a wax printing strategy. After detection of the dengue infection serotype RNA was checked utilizing RT_LAMP [17]. Blood samples were gathered from the patients and they were experienced through Mac-ELISA and NS1 tests for ailment expectation. Re- sults demonstrate the level of dengue in different age gatherings and uncovers that the most astounding number of cases had a place with the age group of 11-30 yrs [14]. Normally clinical examinations include in parcel of human work which prompts misclassification of the affected patient as unaffected patient and thus recognizable proof and finding of an affected patient is critical. Else it now and again prompts demise. To beat the downsides of human work it's smarter to utilize machine learning methods particularly in medicinal area which gives the exact outcomes in the recognizable proof of an affected patient. This inconvenience can be overwhelmed by utilizing machine learning calculations in medicinal and wellbeing spaces which can gives the outcome in less time including less human work and money. Many machine learning algorithms, for example, Naive Bayes, J48, REP Tree, RT, and SMO etc. Out of all these algorithms Naive Bayes and $\mathrm{J} 48$ are the best execution classifier procedures, which takes fewer time to run and shows ROC area 0.815 [10,11]. Artificial Neural Network, ANN is likewise utilized for the forecast of the dengue which takes clinical indications and signs as input and uses multilayer feed-forward neural networks [12, 22]. Correlation among L2 regularized calculated relapse, NB, SVM on 5-overlap stratified cross validation demonstrates that SVM offered the best outcomes measured by ROC-AUC [5]. Not just the above strategies Decision tree is likewise utilized for the forecast and the odds of events of dengue sickness in tribal territory [13]. Decision trees and SVM is likewise utilized as a part of the predicting the disease beforehand which is utilized as a part of the lessening of death rate [3]. Many authors have proposed different techniques for the identification of the disease. In this survey look into paper, we investigate many related research work of the many authors and endeavour to demonstrate it in a tabular form as listed in Table1. 
Table 1: Literature Survey on Dengue fever disease

\begin{tabular}{|c|c|c|c|c|c|}
\hline S.NO & Author & Methodology & Input & Output & Year \\
\hline $\begin{array}{l}\text { [1] A survey Predic- } \\
\text { tion \& Detection } \\
\text { Of Dengue }- \text { Min- } \\
\text { ing Methods \& } \\
\text { Techniques. }\end{array}$ & $\begin{array}{l}\text { Dave Kaveri Atulbhai, } \\
\text { Shilpa Serasiya }\end{array}$ & $\begin{array}{l}\text { Classification techniques } \\
\text { were used for ordering of } \\
\text { dataset such as Naive } \\
\text { Bayesian, REP Tree, Ran- } \\
\text { dom tree, J48, SMO, SVM, } \\
\text { Decision Tree Approach, } \\
\text { and Spatial Data Analysis } \\
\text { etc. }\end{array}$ & $\begin{array}{l}\text { Data set for dengue prediction } \\
\text { is DNA microarray data which } \\
\text { have information of gene's } \\
\text { expression responsible for den- } \\
\text { gue virus. }\end{array}$ & $\begin{array}{l}\text { Comparison among the } \\
\text { techniques concluded } \\
\text { that Naive Bayes } \\
\text { is prominent among all } \\
\text { others as it delivers an } \\
\text { accuracy of } 92 \% \text { with } \\
\text { high probability and } \\
\text { effectiveness }\end{array}$ & 2017 \\
\hline $\begin{array}{l}\text { [2] Association of } \\
\text { rs1285933 single } \\
\text { nucleotide poly- } \\
\text { morphism in } \\
\text { CLEC5A gene with } \\
\text { dengue severity and } \\
\text { its functional ef- } \\
\text { fects. }\end{array}$ & Xavier-Carvalho C, et al., & $\begin{array}{l}\text { PCR test } \\
\text { ELISA test }\end{array}$ & $\begin{array}{l}\text { Patients were assessed every } \\
\text { day amid their hospitalization } \\
\text { for the accompanying parame- } \\
\text { ters: rash, days of fever, ab- } \\
\text { dominal pain, bleeding, plasma } \\
\text { leakage, pleural cavity effusion, } \\
\text { hypotension and leucocytes } \\
\text { levels. }\end{array}$ & $\begin{array}{l}\text { According to SNP analy- } \\
\text { sis, } 80 \% \text { of the patients } \\
\text { were IgG-positive and it } \\
\text { is confirmed that } \\
\text { rs1285933 SNPs doesn't } \\
\text { deviate. }\end{array}$ & 2017 \\
\hline $\begin{array}{l}\text { [3] Dengue disease } \\
\text { prediction using } \\
\text { decision tree and } \\
\text { support vector } \\
\text { machines }\end{array}$ & $\begin{array}{l}\text { Dr.Arun Kumar.P.M, } \\
\text { Chitra Devi.B, Kar- } \\
\text { thick.P, Ganesan.M and } \\
\text { Madhan.A.S }\end{array}$ & $\begin{array}{l}\text { Dataset was experimented } \\
\text { with Weka and Net Beans } \\
\text { IDE. A decision tree is } \\
\text { created utilizing Fisher } \\
\text { Filtering and forecast is } \\
\text { done with the assistance of } \\
\text { Support Vector Machine } \\
\text { (SVM). }\end{array}$ & $\begin{array}{l}\text { Dengue dataset in the form of a } \\
\text { text file is taken and is changed } \\
\text { into excel spread sheet which } \\
\text { acts as the input. }\end{array}$ & $\begin{array}{l}\text { Results will lead in } \\
\text { Predicting the illness } \\
\text { before-hand, which is } \\
\text { utilized in lessening of } \\
\text { mortality rate }\end{array}$ & 2017 \\
\hline $\begin{array}{l}\text { [4] A study of clini- } \\
\text { cal profile in differ- } \\
\text { ent serological } \\
\text { diagnostic parame- } \\
\text { ters of dengue fever }\end{array}$ & $\begin{array}{l}\text { Rohit Morlawar, V. A. } \\
\text { Kothiwale }\end{array}$ & $\begin{array}{l}\text { NS1, IgM, IgG tests were } \\
\text { conducted and a cross } \\
\text { sectional study was done on } \\
\text { the patients with positive } \\
\text { NS1, IgM, IgG tests. }\end{array}$ & $\begin{array}{l}180 \text { dengue fever patients, } \\
\text { positive towards all the tests } \\
\text { were taken as the input. }\end{array}$ & $\begin{array}{l}\text { From the total of } 180 \\
\text { patients, it was observed } \\
\text { that } 72.22 \% \text { of the pa- } \\
\text { tients were males and } \\
\text { male to female propor- } \\
\text { tion was } 2.6: 1\end{array}$ & 2017 \\
\hline $\begin{array}{l}\text { [5] Machine Learn- } \\
\text { ing Models for } \\
\text { Early Dengue } \\
\text { Severity Prediction }\end{array}$ & $\begin{array}{l}\text { William Caicedo- } \\
\text { Torres(B), Angel Pater- } \\
\text { nina, and Hernando } \\
\text { Pinzon }\end{array}$ & $\begin{array}{l}\text { Many Machine Learning } \\
\text { techniques were used such } \\
\text { as } \\
\text { Support Vector Machines } \\
\text { (SVM), L2 Regularized } \\
\text { Logistic Regression and } \\
\text { Naive Bayes Classifier. }\end{array}$ & $\begin{array}{l}\text { Data was collected from the } \\
\text { patients of Hospital which is } \\
\text { used to validate several classifi- } \\
\text { cation models. }\end{array}$ & $\begin{array}{l}\text { All the models were } \\
\text { trained under 5-Fold } \\
\text { Stratified Cross- } \\
\text { Validation and these } \\
\text { outcomes indicate good } \\
\text { prediction capabilities } \\
\text { and SVM offered } \\
\text { the best results measured } \\
\text { by Receiver operating } \\
\text { characteristic area. }\end{array}$ & 2016 \\
\hline $\begin{array}{l}\text { [6] A Data Mining } \\
\text { approach for precise } \\
\text { diagnosis of dengue } \\
\text { fever }\end{array}$ & $\begin{array}{l}\text { M.Bhavani and S.Vinod } \\
\text { kumar }\end{array}$ & $\begin{array}{l}\text { Classification procedures } \\
\text { used are REP Tree, J48, } \\
\text { SVM, ZeroR and Random } \\
\text { Tree. WEKA tool }\end{array}$ & $\begin{array}{l}\text { Dengue Dataset which contains } \\
\text { attributes like fever, bleeding, } \\
\text { metallic taste, Fatigue etc. were } \\
\text { taken as input }\end{array}$ & $\begin{array}{l}\text { After the comparison, } \\
\text { result shows that SVM } \\
\text { and } 48 \text { performs well } \\
\text { than other algorithms, as } \\
\text { they achieved an accura- } \\
\text { cy of } 84 \% \text { and } 76 \% \text { in } \\
\text { anticipating the fever. }\end{array}$ & $\begin{array}{l}\text { Nov } \\
2016\end{array}$ \\
\hline $\begin{array}{l}\text { [7] An epidemio- } \\
\text { logical study of } \\
\text { fever outbreak in } \\
\text { Aurangabad, Maha- } \\
\text { rashtra, India. }\end{array}$ & $\begin{array}{l}\text { Purushottam Kumar, } \\
\text { Rajendra T. Ankushe, } \\
\text { Bina M. Kuril1, Mohan } \\
\text { K. Doibale, Syed J. } \\
\text { Hashmi, Sandeep B. } \\
\text { Pund }\end{array}$ & $\begin{array}{l}\text { IgG, IgM immune response } \\
\text { tests, ELISA and PCR tests. }\end{array}$ & $\begin{array}{l}\text { Input is gathered from hospital } \\
\text { records and Secondary data } \\
\text { from Aurangabad Municipal } \\
\text { Corporation and meteorological } \\
\text { department. }\end{array}$ & $\begin{array}{l}\text { Out of } 308 \text { cases, } 56 \\
\text { were NS1 positive. Most } \\
\text { extreme dengue cases } \\
(41 \%) \text { were found in } 11 \\
\text { to } 20 \text { year age group. } \\
\text { From } 56 \text { analyzed cases a } \\
\text { total of } 8 \text { cases confront- } \\
\text { ed demise because of } \\
\text { DHF/DSS. }\end{array}$ & 2016 \\
\hline $\begin{array}{l}\text { [8] Decision trees } \\
\text { for diagnosis of } \\
\text { dengue fever }\end{array}$ & $\begin{array}{l}\text { Phong D. Tong, Vinh D. } \\
\text { Le, Hieu N. Duong, Hien } \\
\text { T. Nguyen, Vaclav Sna- } \\
\text { sel }\end{array}$ & $\begin{array}{l}\text { C4.5 algorithm for the } \\
\text { generation of decision tree. }\end{array}$ & $\begin{array}{l}\text { Datasets were gathered from } \\
\text { hospital for tropical diseases, } \\
\text { Ho chi minh city, Vietnam, } \\
\text { which incorporate } 8000 \text { medical } \\
\text { records. }\end{array}$ & $\begin{array}{l}\text { C4.5 is certainly fitting } \\
\text { for conclusion of dengue } \\
\text { fever as it has acquired } \\
98 \% \text { accuracy. }\end{array}$ & 2016 \\
\hline $\begin{array}{l}\text { [9] Infection of the } \\
\text { central nervous } \\
\text { system with dengue } \\
\text { virus } 3 \\
\text { Genotype causing } \\
\text { neurological mani- } \\
\text { festations in Brazil }\end{array}$ & $\begin{array}{l}\text { Danilo Bretas de } \\
\text { Oliveira, et al., }\end{array}$ & $\begin{array}{l}\text { Electroencephalogram, pcr } \\
\text { test, RT-pcr test }\end{array}$ & $\begin{array}{l}\text { Cerebrospinal fluid(csf) is gath- } \\
\text { ered from } 21 \text { year old patient } \\
\text { and RNA is extracted for testing }\end{array}$ & $\begin{array}{l}\text { DENV infection in cen- } \\
\text { tral nervous system(cns) } \\
\text { caused by DENV3 geno- } \\
\text { type I is detected }\end{array}$ & 2015 \\
\hline $\begin{array}{l}\text { [10] Dengue disease } \\
\text { prediction using } \\
\text { Weka data mining } \\
\text { tool }\end{array}$ & $\begin{array}{l}\text { Kashish Ara Shakil, } \\
\text { Shadma Anis and Mansaf } \\
\text { Alam }\end{array}$ & $\begin{array}{l}\text { WEKA, a data mining tool } \\
\text { is used in the } \\
\text { Comparison of different } \\
\text { data mining algorithms }\end{array}$ & Dengue dataset & $\begin{array}{l}\text { Comparative study } \\
\text { shows that Naïve Bayes } \\
\text { is } 100 \% \text { accurate and } \mathrm{J} 48 \\
\text { is } 99.70 \% \text { accurate. }\end{array}$ & 2015 \\
\hline $\begin{array}{l}\text { [11] Dengue Fever } \\
\text { Prediction: A Data } \\
\text { Mining Problem }\end{array}$ & $\begin{array}{l}\text { Kamran Shaukat, Nayyer } \\
\text { Masood, Sundas } \\
\text { Mehreen and Ulya } \\
\end{array}$ & $\begin{array}{l}\text { WEKA, a data mining tool. } \\
\text { Classification techniques } \\
\text { used are NB, REP Tree, }\end{array}$ & $\begin{array}{l}\text { Dengue dataset was taken from } \\
\text { the District Headquarter Hospi- } \\
\text { tal, Jhelum. Chunks of data }\end{array}$ & $\begin{array}{l}\text { Results shows that NB } \\
\text { and J48 are the top per- } \\
\text { formance classifier tech- }\end{array}$ & 2015 \\
\hline
\end{tabular}




\begin{tabular}{|c|c|c|c|c|c|}
\hline & Azmeen & RT, J48 and SMO. & $\begin{array}{l}\text { were selected from the dataset } \\
\text { which was treated as Training } \\
\text { set and is tested on WEKA tool. }\end{array}$ & $\begin{array}{l}\text { niques as they are } 92 \% \\
\text { and } 88 \% \text { accurate respec- } \\
\text { tively. }\end{array}$ & \\
\hline $\begin{array}{l}\text { [12] Prediction of } \\
\text { Dengue Outbreaks } \\
\text { in Sri Lanka using } \\
\text { Artificial Neural } \\
\text { Networks }\end{array}$ & $\begin{array}{l}\text { P.H.M.Nishanthi Herath, } \\
\text { A.A.I. Perera, } \\
\text { H.P.Wijekoon }\end{array}$ & $\begin{array}{l}\text { ANN is designed for the } \\
\text { forecast of Dengue out- } \\
\text { breaks and it is a Multi- } \\
\text { Layer Perceptron (MLP) } \\
\text { network connects with } \\
\text { three introductory layers. }\end{array}$ & $\begin{array}{l}\text { Correlation analysis is done on } \\
\text { every individual variable with } \\
\text { the dengue cases revealed. } \\
\text { Variables with the highest } \\
\text { correlation are selected as input } \\
\text { to the ANN. }\end{array}$ & $\begin{array}{l}\text { ANN generates predic- } \\
\text { tions with an accuracy of } \\
68.5 \%, \text { which implies } \\
\text { that } 68.5 \% \text { of the pro- } \\
\text { duced prediction exists in } \\
25 \% \text { tolerance of the } \\
\text { actual reported cases. }\end{array}$ & 2014 \\
\hline $\begin{array}{l}\text { [13] Classification } \\
\text { Rules Using Deci- } \\
\text { sion Tree for Den- } \\
\text { gue Disease }\end{array}$ & $\begin{array}{l}\text { NK Kameswara Rao, Dr. } \\
\text { G P Saradhi Varma, } \\
\text { Dr.M.Nagabhushana Rao }\end{array}$ & $\begin{array}{l}\text { The objective is to creating } \\
\text { a prediction model, Deci- } \\
\text { sion tree. }\end{array}$ & $\begin{array}{l}\text { A total of } 2424 \text { records were } \\
\text { gathered from } \\
\text { various sources. }\end{array}$ & $\begin{array}{l}\text { Decision tree predicts the } \\
\text { chances of occurrences } \\
\text { of dengue diseases in a } \\
\text { tribal area. }\end{array}$ & 2014 \\
\hline $\begin{array}{l}\text { [14] A Comprehen- } \\
\text { sive Study on the } \\
2012 \text { Dengue Fever } \\
\text { Outbreak in } \\
\text { Kolkata, India }\end{array}$ & $\begin{array}{l}\text { Bhaswati Bandyopadh- } \\
\text { yay, et al., }\end{array}$ & $\begin{array}{l}\text { MAC-ELISA, NS } 1 \text { ELI- } \\
\text { SA, RT-PCR } \\
\text {, NS1 antigen detection }\end{array}$ & $\begin{array}{l}\text { Blood samples were collected } \\
\text { from each patient suspected to } \\
\text { be } \\
\text { experiencing dengue, no less } \\
\text { than } 5 \text { days after onset of fever }\end{array}$ & $\begin{array}{l}\text { The percentage of den- } \\
\text { gue cases in different age } \\
\text { groups. It clearly reveals } \\
\text { that the highest number } \\
\text { of cases belonged to the } \\
\text { age group of 11-30 } \\
\text { years. }\end{array}$ & 2013 \\
\hline $\begin{array}{l}\text { [15] A study of } \\
\text { clinical and labora- } \\
\text { tory profile of den- } \\
\text { gue fever in a ter- } \\
\text { tiary care centre of } \\
\text { Uttarakhand, India }\end{array}$ & $\begin{array}{l}\text { Ragini Singh, S. P. } \\
\text { Singh, Niaz Ahmad }\end{array}$ & $\begin{array}{l}\text { Patients of age } 12 \text { or above, } \\
\text { who was antigen or anti- } \\
\text { body positive were incor- } \\
\text { porated in the study. All } \\
\text { such patients who were } \\
\text { admitted in the hospital } \\
\text { underwent through detailed } \\
\text { clinical investigation. }\end{array}$ & $\begin{array}{l}140 \text { patients with dengue fever } \\
\text { was given as the input for the } \\
\text { clinical manifestation }\end{array}$ & $\begin{array}{l}\text { Thrombocytopenia was } \\
\text { the common haematolog- } \\
\text { ical abnormality. Sple- } \\
\text { nomegaly, hepatomegaly, } \\
\text { and hepatosplenomegaly, } \\
\text { were common findings. } \\
\text { Mortality was seen in } 5 \\
\text { patients. }\end{array}$ & 2013 \\
\hline $\begin{array}{l}\text { [16] A data-driven } \\
\text { epidemiological } \\
\text { prediction method } \\
\text { for dengue out- } \\
\text { breaks using local } \\
\text { and remote } \\
\text { sensing data }\end{array}$ & $\begin{array}{l}\text { Anna L Buczak, Phillip T } \\
\text { Koshute, Steven M Ba- } \\
\text { bin, Brian H Feighner } \\
\text { and Sheryl H Lewis }\end{array}$ & $\begin{array}{l}\text { Prediction method which } \\
\text { uses Fuzzy Association } \\
\text { Rule Mining for extraction } \\
\text { of relationships } \\
\text { among clinical, meteoro- } \\
\text { logical, climatic etc. }\end{array}$ & $\begin{array}{l}\text { Data set includes dengue case } \\
\text { data from 2001-2009 and case } \\
\text { data is collected from the Peru- } \\
\text { vian Ministry of Health. }\end{array}$ & $\begin{array}{l}\text { Incidence of dengue is } \\
\text { predicted three or four } \\
\text { weeks in advance. Test } \\
\text { data for a period } 4-7 \\
\text { weeks from time of pre- } \\
\text { diction yielded a positive, } \\
\text { negative, sensitivity and } \\
\text { specificity values as } \\
0.686,0.976,0.615 \text {, and } \\
0.982 \text { respectively. }\end{array}$ & 2012 \\
\hline $\begin{array}{l}\text { [17] Molecular } \\
\text { level dengue-fever } \\
\text { diagnostics }\end{array}$ & $\begin{array}{l}\text { Shih-Jie Lo, } \\
\text { Da-Jeng Yao, } \\
\text { Shih-Chun Yang }\end{array}$ & $\begin{array}{l}\text { Fever diagnostics by using } \\
\text { a combination of RT- } \\
\text { LAMP and paper based } \\
\text { devices made with the help } \\
\text { of wax printing method. }\end{array}$ & $\begin{array}{l}\text { RT_LAMP products (double } \\
\text { standard DNA) } \\
\text { Amplification of dengue virus } \\
\text { serotype } 2 \text { RNA using RT- } \\
\text { LAMP with concentrations of } \\
\text { virus particles }\end{array}$ & $\begin{array}{l}\text { Detection of virus parti- } \\
\text { cles. }\end{array}$ & 2012 \\
\hline $\begin{array}{l}\text { [19] Clinical Mani- } \\
\text { festations and Trend } \\
\text { of Dengue } \\
\text { Cases Admitted in a } \\
\text { Tertiary Care Hos- } \\
\text { pital, } \\
\text { Udupi District, } \\
\text { Karnataka }\end{array}$ & Ashwini Kumar, et al., & $\begin{array}{l}\text { A record based study is } \\
\text { done to determine the pro- } \\
\text { file and outcome of all } \\
\text { patients with a diagnosis of } \\
\text { dengue, DHF, DSS. }\end{array}$ & $\begin{array}{l}\text { Positive ELISA test cases were } \\
\text { included .Data was collected } \\
\text { based on questionnaire and } \\
\text { analyzed using statistical analy- } \\
\text { sis }\end{array}$ & $\begin{array}{l}\text { Of the total of } 466 \text { cases } \\
\text { admitted during the peri- } \\
\text { od of } 2002-2008,391 \\
\text { had dengue fever, } 41 \text { had } \\
\text { DHF and } 34 \text { had DSS. }\end{array}$ & 2010 \\
\hline $\begin{array}{l}\text { [20] Dengue Fever, } \\
\text { Hawaii, } \\
\text { 2001-2002 }\end{array}$ & Paul V. Effler, et al., & $\begin{array}{l}\text { RNA was extracted using } \\
\text { QI Amp viral RNA } \\
\text { mini kits. } \\
\text { IgM, IgG tests. }\end{array}$ & $\begin{array}{l}1,644 \text { persons in Hawaii were } \\
\text { tested for dengue infection }\end{array}$ & $\begin{array}{l}122 \text { persons are dengue } \\
\text { positive }\end{array}$ & 2005 \\
\hline $\begin{array}{l}\text { [21] A Novel Ap- } \\
\text { proach to Classify } \\
\text { Risk in Dengue } \\
\text { Hemorrhagic Fever } \\
\text { (DHF) Using Bioe- } \\
\text { lectrical } \\
\text { Impedance Analysis } \\
\text { (BIA) } \\
\end{array}$ & Fatimah Ibrahim, et al., & $\begin{array}{l}\text { Classification of DHF } \\
\text { using Biometrical Imped- } \\
\text { ance Analysis(BIA) }\end{array}$ & $\begin{array}{l}\text { BIA measurements are made on } \\
97 \text { male and } 86 \text { female DHF } \\
\text { patients }\end{array}$ & $\begin{array}{l}\text { BIA technique provides } \\
\text { a rapid, non-invasive and } \\
\text { promising method for } \\
\text { classifying and evaluat- } \\
\text { ing risk of DHF patients }\end{array}$ & 2005 \\
\hline $\begin{array}{l}\text { [22] A novel den- } \\
\text { gue fever (DF) and } \\
\text { dengue } \\
\text { haemorrhagic fever } \\
\text { (DHF) analysis } \\
\text { using artificial } \\
\text { neural network } \\
\text { (ANN) }\end{array}$ & $\begin{array}{l}\text { Fatimah Ibrahim, Mohd } \\
\text { Nasir Taib, Wan Abu } \\
\text { Bakar Wan Abas, } \\
\text { Chan Chong Guan, Saa- } \\
\text { diah Sulaiman }\end{array}$ & $\begin{array}{l}\text { Initially, physical } \\
\text { examinations were carried } \\
\text { out and then SPSS software } \\
\text { was used for data analysis. } \\
\text { Finally, ANN was applied } \\
\text { on the dataset using Mat } \\
\text { lab tool. }\end{array}$ & $\begin{array}{l}\text { The input for the ANN is solely } \\
\text { based on the clinical symptoms } \\
\text { which uses multilayer feed- } \\
\text { forward neural networks } \\
\text { (MFNN). }\end{array}$ & $\begin{array}{l}\text { The ANN presented in } \\
\text { the study had successful- } \\
\text { ly yielded promising } \\
\text { results with the error of } \\
\text { only } 10 \% \text {. }\end{array}$ & 2005 \\
\hline $\begin{array}{l}{[23] \text { Dengue Anti- }} \\
\text { body } \\
\text { Prevalence in } \\
\text { German Travelers }\end{array}$ & Ole Wichmann, et al., & IgM, IgG, ELISA test. & $\begin{array}{l}\text { Study was done on } 2,259 \text { citi- } \\
\text { zens of german after they re- } \\
\text { turned from dengue-endemic } \\
\text { countries. }\end{array}$ & $\begin{array}{l}\text { Specific serotypes of } \\
\text { dengue antibodies indi- } \\
\text { cated acute infections in } \\
51 \text { travellers i.e., } 4.7 \% \\
\text { with recent fever and } 13\end{array}$ & 2005 \\
\hline
\end{tabular}




\begin{tabular}{|l|l|l|l|l|}
\hline & & & travellers with no recent \\
fever.
\end{tabular}

\section{Proposed Work}

Consider the proposed machine learning algorithms namely, Multi-Layer Perception, C 4.5, and Simple CART for classification of a patient whether he or she is effected by the disease or not.

A) Simple CART: Classification and regression trees are used to refer classification and regression decision trees. It is structured as a sequence of questions, the answers to which determine what the next question, if any should be. This algorithm mainly performs variable screening or feature selection. It requires relatively less effort from users for data preparation.

B) C-4.5: This algorithm is used to generate decision trees which are used for classification. It is often called as statistical classifier and is easy to build and implement which uses both categorical and continuous values.

C) Multi-Layer Perception: A multilayer perception (MLP) is a class of feed-forward artificial neural system. A MLP comprises of no less than three layers of hubs or nodes. Aside from the info hubs, every hub is a neuron that uses a nonlinear initiation work. MLP uses a regulated learning system called back propagation for training. Its numerous layers and non-direct initiation recognize MLP from a straight perception. It can recognize information that isn't directly separable. Multilayer perceptions are some of the time casually alluded to as "vanilla" neural systems, particularly when they have a solitary concealed layer.

\section{Data Set:}

Consider the attributes of Dengue data set which was collected from various medical wards of Vijayawada hospitals as shown in Table 2.

Table 2: List of Attributes in Dengue fever dataset

\begin{tabular}{|c|c|c|}
\hline Attributes & & Values \\
\hline WBC & & no. of WBC \\
\hline Temperature & & 101 or 102 or 103 \\
\hline Pain & & Behind eyes \\
\hline Abdominal pain & & Yes/No \\
\hline Vomiting & & Yes/No \\
\hline Diarrhoea & & Yes/No \\
\hline Severe headache & & Yes/No \\
\hline Haemoglobin & & Haemoglobin Range \\
\hline Platelets & & Platelets count \\
\hline Dengue & & Yes/No \\
\hline Metallic Taste & & Yes/No \\
\hline Joint/Muscle pain & & Yes/No \\
\hline \multicolumn{3}{|c|}{$\begin{array}{l}\text { For accurate diagnosing, always accuracy performance metric is } \\
\text { not sufficient to determine whether a patient is affected by dengue } \\
\text { disease or not. And hence various performance metrics are used to } \\
\text { measure the classifier's performance are Accuracy, Precision, } \\
\text { Recall and F-measure which are derived from the confusion ma- } \\
\text { trix as defined in Table 3. Classification uses the class values of } \\
\text { Positive, Negative, True Positive, True Negative, False Positive } \\
\text { and False Negative. }\end{array}$} \\
\hline \multicolumn{3}{|c|}{ Table3: Confusion Matrix } \\
\hline $\begin{array}{l}\text { Actual } \\
\text { / Predicted }\end{array}$ & Positive & \begin{tabular}{l|l} 
& Negative
\end{tabular} \\
\hline Positive & $\mathrm{TP}$ & FN \\
\hline
\end{tabular}

\section{\begin{tabular}{|l|l|l} 
Negative & FP & TN \\
\hline
\end{tabular}}

In confusion matrix, the diagonal components are viably gathered data and the straggling leftovers of segments are wrongly requested data. Precision is described as the extent between the honest to goodness positive esteem and both the genuine positive and false positive esteems.

Consider the confusion matrix of proposed algorithms as listed in Tables $-4,5 \& 6$.

Table 4: confusion matrix of $\mathrm{C} 4.5$

\begin{tabular}{|l|c|c|c|}
\hline Actual/Predicted & Positive & Negative & Total \\
\hline Positive & 11 & 1 & 12 \\
\hline Negative & 0 & 8 & 8 \\
\hline
\end{tabular}

There are 12 items found in positive values, 8 items in negative values, 11 in true positive values, 1 in False Negative values, 0 in False Positive values and 8 in True Negative values.

Table 5: confusion matrix of MLP

\begin{tabular}{|l|c|c|c|}
\hline \multicolumn{1}{|c|}{ Tablual/Predicted } & Positive & Negative & Total \\
\hline Positive & 10 & 2 & 12 \\
\hline Negative & 0 & 8 & 8 \\
\hline
\end{tabular}

There are 12 items found in positive values, 8 items in negative values, 10 in true positive values, 2 in False Negative values, 0 in False Positive values and 8 in True Negative values.

Table 6: confusion matrix of Simple CART

\begin{tabular}{|l|l|l|l|}
\hline Actual /Predicted & Positive & Negative & Total \\
\hline Positive & 12 & 0 & 12 \\
\hline Negative & 0 & 8 & 8 \\
\hline
\end{tabular}

There are 12 items found in positive values, 8 items in negative values, 12 in true positive values, 0 in False Negative values, 0 in False Positive values and 8 in True Negative values.

Let us define the performance metrics on classification of patient as stated below:

A. Accuracy: It is calculated as the extent of true positive, true negatives and true outcomes from the given information.

Accuracy $=[\mathrm{TP}+\mathrm{TN}] /[\mathrm{TP}+\mathrm{FN}+\mathrm{FP}+\mathrm{TN}]$

B. Precision: It is also called as positive predictive value which is the part of significant cases among recovered instances.

Precision $=\mathrm{TP} /[\mathrm{TP}+\mathrm{FP}]$

C. Recall: It is defined as sensitivity which is the fraction of relevant instances that have been retrieved over the total amount of relevant or applicable instances.

Recall $=\mathrm{TP} /[\mathrm{TP}+\mathrm{FN}]$

D. F-Measure: This is assessed by the consonant mean amongst accuracy and review.

F-Measure $=2 *[$ Precision $*$ Recall $] /[$ Precision + Recall $]$

\section{Results}

Consider the classification performance of machine learning algorithms MLP, C4.5, Simple CART on 20 patient's / samples of dengue fever data set as defined in the Table -7 as follows:

Table 7: Classification ratio of machine learning algorithms - MLP, Decision Tree-C4.5 and Simple CART.

\begin{tabular}{|l|c|c|}
\hline Algorithm & $\begin{array}{l}\text { Correctly Classified } \\
\text { Patient's }\end{array}$ & $\begin{array}{l}\text { Incorrectly Classified } \\
\text { Patient's }\end{array}$ \\
\hline MLP & 18 & 2 \\
\hline $\begin{array}{l}\text { Decision Tree - } \\
\text { C4.5 }\end{array}$ & 19 & 1 \\
\hline
\end{tabular}




\section{Simple CART}

20

Based on the classification ratio and Confusion matrix the evaluation of performance metrics of proposed classifiers are shown in the Figures 1 and 2 as follows. Accuracy graph is plotted based on the results of proposed algorithms using true positives, true negatives, false positives and false negative values.

\section{Accuracy}

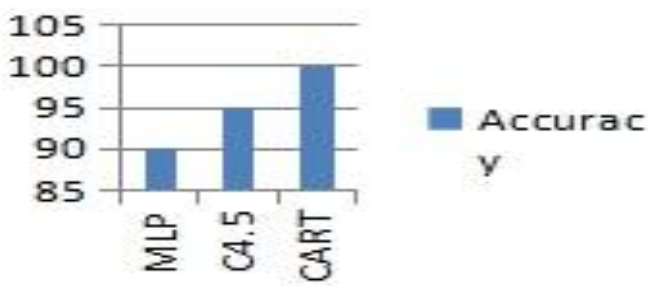

Fig 1: Accuracy comparison study of classifier's - MLP,C4.5 \& CART.

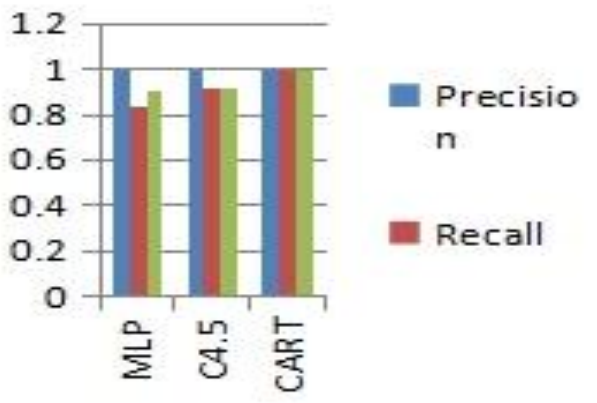

Fig 2: Comparison study of Precision, Recall, F-Measure metrics on classifiers - MLP, C4.5 \& CART.

\section{Conclusion:}

Human therapeutic data is quickly the most satisfying, troublesome, as each and every normal data must be isolated and broke down. Isolating helpful data, finding patterns and classifying the data involves an intelligent decision making for the examination and treatment of disease in which the database gets the opportunity to be fundamentally unmistakable. Machine learning procedures will lead us to an answer for this issue. A noteworthy target is to utilize machine learning algorithms in medicinal and health applications that can help in taking exact choices. Here, machine learning assumes a critical part in giving outcomes quicker and precise by utilizing different algorithms. Computational methodologies like these are intriguing; since they can be deployed utilizing individual gadgets like portable workstations, cell phones or tablets in a cheap and pragmatic way; and once prepared, factual and Machine Learning models can offer a prediction in seconds. Based on the experimental analysis done on MLP, C4.5 and Simple CART algorithms, Simple CART shows the best results in all performance metrics like Accuracy, Precision, Recall and Fmeasure metrics which is the best classifier for classification of a person whether he or she effected by dengue disease or not.

\section{References}

[1] Dave Kaveri Atulbhai and Shilpa Serasiya, "A Survey: Prediction \& Detection of Dengue - Mining Methods \& Techniques, IJARIIE-ISSN (O)-2395-4396, Vol-3, Issue-2, 2017.

[2] Xavier-CarvalhoC, Cezar RDDS, Freire NM, Vasconcelos CMM, Solorzano VEF, de Toledo-Pinto TG, Fialho LG, do Carmo RF, Vasconcelos LRS, Cordeiro MT,

[3] Dr.Arun Kumar.P.M, Chitra Devi.B, Karthick.P, Ganesan.M and Madhan.A.S, "Dengue Disease Prediction Using Decision Tree and Support Vector Machine", www.internationaljournalssrg.org, ISSN: $2348-8387,2017$, pp: 60-63.
[4] Rohit Morlawar, V.A. Kothiwale, "A study of clinical profile in different serological diagnostic parameters of dengue fever", 2017, Volume: 10, Issue: 2, pp: 178-182

[5] William Caicedo-Torres, Angel Paternina, and Hernando Pinzon, "Machine Learning Models for Early Dengue Severity Prediction", @ Springer International Publishing AG 2016

[6] M. Montes-y-Gomez et al. (Eds.): IBERAMIA 2016, LNAI 10022 , pp. 247-258, 2016, DOI: 10.1007/978-3-319-47955-2 21

[7] M.Bhavani and S.Vinod kumar, "A Data Mining Approach For Precise Diagnosis of Dengue Fever", International Journal of Latest Trends in Engineering and Technology, Vol (7), Issue(4), pp.352359, nov 2016, DOI: http://dx.doi.org/10.21172/1.74.048

[8] Purushottam Kumar, Rajendra T. Ankushe, Bina M. Kuril1, Mohan K. Doibale, Syed J. Hashmi, Sandeep B. Pund, "An Epidemiological Study of Fever Outbreak in Aurangabad, Maharashtra, India", International Journal of Community Medicine and Public Health Kumar P et al. Int J Community Med Public Health. 2016 May; 3(5), pp: 1107-1111

[9] Phong D. Tong, Vinh D. Le, Hieu N. Duong, Hien T. Nguyen, Vaclav Snasel, "Decision trees for diagnosis of dengue fever", International Conference on Information and Convergence Technology for Smart Society, Jan 2016, 19-21, in Ho Chi Minh, Vietnam

[10] Danilo Bretas de Oliveira, Guilherme Machado, Gabriel Magno de Freitas Almeida, Paulo Cesar Peregrino Ferreira, Claudio Antonio Bonjardim, Giliane de Souza Trindade, Jonatas Santos Abrahao and Erna Geessien Kroon, "Infection of the central nervous system with dengue virus 3 genotype I causing neurological manifestations in Brazil", Revista da Sociedade Brasileira de Medicina Tropical 49(1):125-129, Jan-Feb, 2016, http://dx.doi.org/10.1590/00378682-0208-2015

[11] Kashish Ara Shakil, Shadma Anis and Mansaf Alam, "Dengue Disease Prediction using Weka Data Mining Tool”, 18 Feb 2015.

[12] Kamran Shaukat, Nayyer Masood, Sundas Mehreen and Ulya Azmeen, "Dengue Fever Prediction: A Data Mining Problem", Dar et al., J Data Mining Genomics Proteomics 2015, 6:3 http://dx.doi.org/10.4172/2153-0602.1000181

[13] P.H.M.Nishanthi, Herath, A.A.I., Perera, H.P.Wijekoon, "Prediction of Dengue Outbreaks in Sri Lanka using Artificial Neural Networks", International Journal of Computer Applications (0975 8887) Volume 101- No.15, September 2014

[14] N K Kameswara Rao, Dr. G P Saradhi Varma, Dr.M.Nagabhushana Rao, "Classification Rules Using Decision Tree for Dengue Disease", International Journal of Research in Computer and Communication Technology, Vol 3, Issue 3, March- 2014.

[15] Bhaswati Bandyopadhyay, Indrani Bhattacharyya, Jayshree Konar, Srima Adhikary, Nidhi Dawar, Jayeeta Sarkar,1 SaiantaniMondal, Mayank Singh Chauhan, Nemai Bhattacharya, Asit Biswas, Anita Chakravarty, and Bibhuti Saha, "A Comprehensive Study on the 2012 Dengue Fever Outbreak in Kolkata, India”, Hindawi Publish ing Corporation, ISRN Virology, Article ID 207580, Volume 2013, 5.pages, http://dx.doi.org/10.5402/2013/207580.

[16] Ragini Singh, S. P. Singh, Niaz Ahmad. "A study of clinical and laboratory profile of dengue fever in a tertiary care centre of Uttarakhand, India", International Journal of Research in Medical Sciences, Singh R et al. Int J Res Med Sci., 2014 Feb; 2(1), pp: 160163

[17] Anna L Buczak, Phillip T Koshute, Brian H Feighner, Steven M Babin and Sheryl H Lewis, "A data-driven epidemiological prediction method for dengue outbreak using local and remote sensing data", Buczak et al. BMC Medical Informatics and Decision Making 2012, 12:124, http://www.biomedcentral.com/1472-6947/12/124

[18] Shih-Jie lo, Shih_Chun Yang, Da_Jeng Yao, Jianm_Hwa Chen, Chao_Min Cheng. "Molecular-Level Dengue Fever Diagnostics", December 2012, IEEE nanotechnology magazine, pp: 26-30.

[19] Daranee Thitiprayoonwongse, Pratap Suriyaphol and Nuanwan Soonthornphisaj. "Data Mining of Dengue Infection Using Decision Tree”, ISBN: 978-1-61804-092-3, 2012, pp: 154-159.

[20] Ashwini Kumar, Chythra R Rao, Vinay Pandit, Seema Shetty, Chanaveerappa Bammigatti, Charmaine Minoli Samarasinghe, "Clinical Manifestations and Trend of Dengue Cases Admitted in a Tertiary Care Hospital, Udupi District, Karnataka", Indian Journal of Community Medicine, Issue 3, Vol 35, July 2010, pp: 386-390.

[21] Paul V. Effler, Lorrin Pang, Paul Kitsutani, Vance Vorndam, Michele Nakata, Tracy Ayers, Joe Elm, Tammy Tom, Paul Reiter, José G. Rigau-Perez, John M. Hayes, Kristin Mills, Mike Napier, Gary G. Clark, and Duane J. Gubler. "Dengue Fever, Hawaii, 2001-2002”, Emerging Infectious Diseases, www.cdc.gov/eid, Vol. 11, No. 5, May 2005, pp: 742-749.

[22] Fatimah Ibrahim, Mohd Nasir Taib, Senior Member, IEEE, Wan Abu Bakar Wan Abas, Chan Chong Guan, and Saadiah Sulaiman. 
"A Novel Approach to Classify Risk in Dengue Hemorrhagic Fever (DHF) Using Bioelectrical Impedance Analysis (BIA)", IEEE Transactions on Instrumentation and Measurement, VOL. 54, NO.1, Feb 2005, pp: 237-244.

[23] Fatimah Ibrahim, Mohd Nasir Taib, Senior Member, IEEE, Wan Abu Bakar Wan Abas, Chan Chong Guan, and Saadiah Sulaiman, "A novel dengue fever (DF) and dengue haemorrhagic fever (DHF) analysis using artificial neural network (ANN)", Computer Methods and Programs in Biomedicine (2005) 79, pp: 273-281.

[24] Ole Wichmann, Annekathrin Lauschke, Christina Frank, Pei-Yun Shu, Matthias Niedrig, Jyh-Hsiung Huang, Klaus Stark, and Tomas Jelinek, "Dengue Antibody Prevalence in German Travelers", Emerging Infectious Diseases www.cdc.gov/eid, Vol. 11, No.5, May 2005, pp: 762-766.

[25] Nivedita Gupta, Sakshi Srivastava, Amita Jain \& Umesh C. Chaturvedi, "Dengue in India”, Indian J Med Res 136, September 2012, pp: 373-390

[26] http://www.denguevirusnet.com/aedes-aegypti.html

[27] J. Jain, S.K. Dubey, J. Shrinet, S. Sunil, "Dengue Chikungunya coinfection: A live-in relationship", Biochemical and Biophysical Research Communications,

[28] Rasana Patil, Tina Makhija, H. P. Suryawanshi, S.P.Pawar.A Review on - Dengue.Research J. Pharm. and Tech. 6(9): September 2013.

[29] Baheerati M.M.Natural Therapy for Dengue Fever.Research J. Pharm. and Tech. 7(2): February 2014

[30] D.Sunitha, K.Hemalatha, M.Nandha Kishora Chary, Rahamat Unissa.A Review on Zika Virus.Asian J. Pharm. Res. 2016; Vol. 6: Issue 3

[31] Meena Kumari Bimal, Ms.Lakhbir Kaur2, Ms.Mandeep Kaur.Assessment of Knowledge and Practices of People Regarding Dengue Fever.International Journal of Nursing Education and Research 4(2):174-178; April- June 2016; DOI: 10.5958/24542660.2016.00035.1.

[32] Mukesh Bachwani, Vandana Sharma, Shikha Jhakotiya, Rakesh Kumar, Pramod Bijarnia, Yojna Upadhaya.Chikungunya: A Review.Research J. Pharmacology and Pharmacodynamics; 4(1): 2012 $62-73$

[33] Thakur Akash U., Popat Ritesh R., Mhaske Shivshankar D., Narkhede Mahesh B.,Chinchole Pavan P., Shrikhande Vinayak N.;Zika Virus Disease- Review.Research Journal of Pharmacology and Pharmacodynamics. 9(2): 101-114; April-June 2017.

[34] NS Dighe, SR Pattan, SB Dighe, SB Bhawar, RB Saudagar,V M Gaware, MB Hole and VB Tambe.Chikungunya Disease: A Review.Research J. Pharmacology and Pharmacodynamics 2009; 1(1):07-12.

[35] Dhrubo Jyoti Sen, Jimit S. Patel, Charoo S. Garg, Divyang H. Shah, Kiran M. Patel, Dhara S. Bhavsar, Tirtha V. Patel, Dhara M. Limbachia:Research J. Science and Tech. 3(3):May-June. 2011: 119-126.

[36] Mr.E.Shanumuga priya,Dr.V.Ravichandiran,Dr.M.Vijey Aanandhi :Molecular docking studies on naturally occuring selected flavones against protease enzyme of dengue virus:Research J.pharm and Tech.9 (7): July 2016

[37] Mr.Sanjay S.Shinde,Mr.Frew.T:Dengue fever:A Review,International journal of advances in nursing management.2016;4(2):161-163.

[38] Dr. Seetaiah Kilaru, Hari Kishore K, Sravani T, Anvesh Chowdary L, Balaji T "Review and Analysis of Promising Technologies with Respect to fifth Generation Networks", 2014 First International Conference on Networks \& Soft Computing, ISSN:978-1-47993486-7/14,pp.270-273, August2014. 